Photoelectrochemical System for Unassisted High-Efficiency Water-Splitting Reactions Using

\title{
$\mathrm{N}$-Doped $\mathrm{TiO}_{2}$ Nanotubes
}

\author{
M. Praveen Kumar, R. Jagannathan and S. Ravichandran* \\ CSIR - Central Electrochemical Research Institute, Karaikudi - 630 003, India.
}

Corresponding authors: S. Ravichandran* 


\section{Raman spectra}

Figure $\mathrm{S} 1$ shows the Raman mapping and corresponding spectra of bare titanium, bare $\mathrm{TiO}_{2}$ and $\mathrm{N}$-doped $\mathrm{TiO}_{2}$ nanotubes samples. From the images, the surface modification is due to changes in elemental composition, as we proceed from titanium to $\mathrm{N}$-doped $\mathrm{TiO}_{2}$ nanotubes (Figure $\mathrm{S} 1$ (a-c)). Generally, the Raman active fundamental modes of bare $\mathrm{TiO}_{2}$ anatase phase can be observed at around $144 \mathrm{~cm}^{-1}\left(\mathrm{E}_{\mathrm{g}}\right), 397 \mathrm{~cm}^{-1}\left(\mathrm{~B}_{1 \mathrm{~g}}\right), 518 \mathrm{~cm}^{-1}\left(\mathrm{~A}_{1 \mathrm{~g}}+\mathrm{B}_{1 \mathrm{~g}}\right)$ and $640 \mathrm{~cm}^{-1}\left(\mathrm{E}_{\mathrm{g}}\right)^{1}$. Moreover, the Raman peaks below $200 \mathrm{~cm}^{-1}$ can't be taken into account since it comes from the filter (excitation light). ${ }^{1}$ Also, the Raman spectra of titanium, bare $\mathrm{TiO}_{2}$ nanotubes, and $\mathrm{N}$-doped $\mathrm{TiO}_{2}$ nanotubes are shown in Figure S1d. From the spectra, the titanium metal doesn't reveal any Raman peak since the metal surface is Raman inactive in nature. However, presence of Raman active peaks at 398, 516, 635 for bare $\mathrm{TiO}_{2}$ and 396, 519, $638 \mathrm{~cm}^{-1}$ for $\mathrm{N}$-doped $\mathrm{TiO}_{2}$ nanotubes is mainly attributed to the vibrational modes of the anatase phase. ${ }^{1}$ The notable peak shift occurred in case of $\mathrm{N}$-doped $\mathrm{TiO}_{2}$ nanotubes (Figure. S1e, enlarged spectra, i.e. $398 \mathrm{~cm}^{-1}$ to 396 $\mathrm{cm}^{-1}$ ) can be regarded as red shift due to doping of nitrogen in the $\mathrm{TiO}_{2}$ nanotubes. ${ }^{1}$ Further, the shift in Raman peaks from 516 to $519 \mathrm{~cm}^{-1}$ and 636 to $638 \mathrm{~cm}^{-1}$ is due to the blue shift arising from $\mathrm{N}$-doped $\mathrm{TiO}_{2}$ nanotubes. ${ }^{1}$

\section{FT-IR spectra}

The nitrogen doping in $\mathrm{TiO}_{2}$ lattice was further confirmed by the FT-IR analysis. Figure S2 shows FT-IR spectra of titanium metal, bare $\mathrm{TiO}_{2}$ nanotube and $\mathrm{N}$-doped $\mathrm{TiO}_{2}$ nanotubes. In case of titanium metal no characteristic vibrational peaks observed due to the absence of functional groups on the metal surface. However, the titanium metal surface after oxidation is transformed into $\mathrm{TiO}_{2}$, which shows the characteristic Ti-O vibrational peaks in the FT-IR spectrum (Figure S2). ${ }^{2}$ Whereas, the nitrogen doped $\mathrm{TiO}_{2}$ nanotubes show a well defined peaks 
at around 1320 and $1680 \mathrm{~cm}^{-1}$ corresponding to O-Ti-N and O-Ti-N-OH vibrations, respectively. ${ }^{3-5}$

\section{Electron Paramagnetic Resonance (EPR) measurement}

Earlier, J. Dong et al. ${ }^{6}$ recorded EPR spectrum for commercial Degusa P25 $\mathrm{TiO}_{2}$ and reported that the sample not showing any paramagnetic signal. However, the EPR spectrum of bare $\mathrm{TiO}_{2}$ (Figure S2) recorded at room temperature shows a weak signal due to the presence of oxygen vacancies in $\mathrm{TiO}_{2}$ nanotubes. ${ }^{6}$ It eventually indicates that the electrons are trapped on $\mathrm{Ti}^{4+}$ surface in bare $\mathrm{TiO}_{2}$ nanotubes. ${ }^{6}$ The bare $\mathrm{TiO}_{2}$ nanotubes shows g-factor value of $\mathrm{g}=2.094$ (Figure S2) and this weak signal confirms the electrons entrapment in oxygen vacancies. ${ }^{7,8}$ Further, the $\mathrm{TiO}_{2}$ nanotubes were modified by doping of nitrogen element and the EPR spectrum of $\mathrm{N}$-doped $\mathrm{TiO}_{2}$ nanotubes shows an intense peak with g-factor value at 2.434 as shown in Figure $\mathrm{S} 2 .^{7}$ The g-factor value is shifted to higher value for $\mathrm{N}$-doped $\mathrm{TiO}_{2}$ nanotubes compared to bare $\mathrm{TiO}_{2}$ nanotubes, i.e. 2.094 to 2.434 . The observed phenomenon in EPR spectra is mainly due to the doping of nitrogen which increases the free electron on the surface of $\mathrm{TiO}_{2}$ nanotubes with high oxygen vacancies. ${ }^{8}$ Moreover, the EPR spectra also depict clear information on oxygen vacancies as well as free electrons present in $\mathrm{N}$-doped $\mathrm{TiO}_{2}$ nanotubes, which can enhance the photoelectrochemical activity in water splitting reaction. ${ }^{8}$

\section{Surface morphology analysis}

The surface FE-SEM images of titanium metal before and after oxidation are shown in Figure S4. Before oxidation process, the surface of titanium metal is very smooth as expected, since there is no electrochemical reaction at this stage (Figure $\mathrm{S} 4 \mathrm{a}$ ). However, the $\mathrm{TiO}_{2}$ nanotubes were grown on the surface of titanium metal foil during the oxidation process (Figure S4b). The $\mathrm{TiO}_{2}$ nanotubes were grown in controlled size (width and length) and morphology on titanium 
substrate in Figure S4b. The FE-SEM micrograph of $\mathrm{N}$-doped $\mathrm{TiO}_{2}$ nanotubes illustrated in Figure $\mathrm{S} 4 \mathrm{c}$ and $\mathrm{S} 4 \mathrm{~d}$, clearly shows that he surface morphology of $\mathrm{TiO}_{2}$ and the changes are more pronounced in the cross sectional image of $\mathrm{N}$-doped $\mathrm{TiO}_{2}$ nanotubes (Figure $\mathrm{S} 4 \mathrm{~d}$ ). At different anodization time, the surface morphology of $\mathrm{N}$-doped $\mathrm{TiO}_{2}$ nanotubes have transformed and it was clearly observed in Figure S4 $\left(\mathrm{a}_{1}-\mathrm{d}_{1}\right)$.

Figure S5 depicts surface morphology and crystalline patterns of bare and $\mathrm{N}$-doped $\mathrm{TiO}_{2}$ nanotubes using TEM and SAED analysis. The TEM images of $\mathrm{TiO}_{2}$ nanotubes (Figure S5a) illustrate nano sized tube formation and the corresponding SAED pattern (Figure S5b) coincides well with XRD pattern; reveal the mixed phases of anatase (101), rutile (101) and titanium metal (004). To be noted, Figure $\mathrm{S} 5 \mathrm{c}$ shows porous morphology on the surface of $\mathrm{N}$-doped $\mathrm{TiO}_{2}$ nanotubes which are not present in bare $\mathrm{TiO}_{2}$ nanotubes. This is a contrasting result that exclusively observed in $\mathrm{N}$-doped $\mathrm{TiO}_{2}$ nanotubes than bare nanotubes. Moreover, the high magnification image (as inset in Figure. S5C) also is confirms the nanotubes with porous morphology on the surface. Figure 8d shows corresponding SAED pattern of $\mathrm{N}$-doped $\mathrm{TiO}_{2}$ nanotubes that clearly indicates the presence of solely anatase phase with lattice planes of (101), (103) and (200).

\section{Atomic Force Microscopy (AFM)}

AFM topographic and 3D images are represents surface of titanium foil (before anodization process) has been smooth surface morphology in Figure S6 $\mathrm{a}_{\mathrm{a}} \mathrm{a}_{1}$. The surface of bare and Ndoped $\mathrm{TiO}_{2}$ nanotubes were disturbed by anodization process and it was observed clearly in AFM images (Figure $\mathrm{S} 6 \mathrm{~b}, \mathrm{~b}_{1}, \mathrm{c}$ and $\mathrm{c}_{1}$ ). This is indicating oxide layer formed on the surface of titanium by changes the surface roughness of $2.8 \mathrm{~nm}$. 


\section{Electrochemical Impedance Spectroscopy (EIS)}

Figure S7A shows the impedance spectra of bare and $\mathrm{N}$-doped $\mathrm{TiO}_{2}$ nanotubes. The diameter of the semicircle in Nyquist plot reflects the reaction kinetics as well as the charge transfer properties between electrode and electrolyte interface. From the graph, the diameter of $\mathrm{N}$-doped $\mathrm{TiO}_{2}$ nanotubes is smaller than bare $\mathrm{TiO}_{2}$ nanotubes under visible light illumination. It clearly indicates the low charge transfer resistance for $\mathrm{N}$-doped $\mathrm{TiO}_{2}$ nanotubes due to doping of nitrogen into $\mathrm{TiO}_{2}$ lattice. Further, we calculated flat-band potential of -1.2 for bare $\mathrm{TiO}_{2}$ nanotubes and -1.4 for $\mathrm{N}$-doped $\mathrm{TiO}_{2}$ nanotubes. This result has indicated Fermi level towards close to conduction band (as shown Figure S7B).

\section{Intensity Modulated Photovoltage Spectroscopy (IMVS) analysis}

The IMVS studies shows that the semicircle is display at low frequency for $\mathrm{N}$-doped $\mathrm{TiO}_{2}$ nanotubes compare to bare $\mathrm{TiO}_{2}$ nanotubes in Figure $\mathrm{S} 8 \mathrm{a}$ and c. The charge transfer and electron-hole recombination can alter by doping of nitrogen into $\mathrm{TiO}_{2}$ lattice. Further as shown in Figure $\mathrm{S} 8 \mathrm{~b}$, the rate constant of $\mathrm{N}$-doped $\mathrm{TiO}_{2}$ nanotubes are very less value of $0.050 \mathrm{~S}^{-1}$ at the $-0.14 \mathrm{~V}$ compare to bare $\mathrm{TiO}_{2}$ nanotubes (rate constant value of $0.125 \mathrm{~S}^{-1}$ at $-0.14 \mathrm{~V}$ ) in Figure S8 d.

\section{PEC water splitting measurement}

T. E. Mallouk et al. found that $\mathrm{pH}$ gradient for PEC water splitting. ${ }^{9}$ In PEC, we were studied $\mathrm{pH}$ gradients formation to increase the hydrogen generation. The $\mathrm{pH}$ gradients formation may minimize the voltage lost and improve stability of photoanode in PEC water oxidation process. The rate of water dissociation in the $1 \mathrm{M} \mathrm{NaOH}(14 \mathrm{pH}) / 1 \mathrm{M} \mathrm{H}_{2} \mathrm{SO}_{4}(1 \mathrm{pH})$ is equal to the rate of consumption of the protons and hydroxide ions at the electrode surfaces 
(electrodialysis); a steady-state $\mathrm{pH}$ gradient is maintained. ${ }^{10,11}$ Further, the $\mathrm{pH}$ gradients mechanism involved for unassisted PEC water splitting thorough chemical bias assisting electron transfer between electrode and electrolyte interface. ${ }^{12-14}$ Accordingly, Figure S9a represents the outdoor photo-electrochemical water-splitting of bare $\mathrm{TiO}_{2}$ and $\mathrm{N}$-doped $\mathrm{TiO}_{2}$ nanotubes under direct sunlight in aqueous electrolytes of $1 \mathrm{M} \mathrm{NaOH}(14 \mathrm{pH}) / 1 \mathrm{M} \mathrm{H}_{2} \mathrm{SO}_{4}(1 \mathrm{pH})$ solution (scheme $\mathrm{S} 2$ ). The photocurrent density of bare $\mathrm{TiO}_{2}$ nanotubes reached upto the maximum of $0.3 \mathrm{~mA} / \mathrm{cm}^{2}$ under intense sunlight (100000 lux) condition. In general, the photocurrent increase with increasing intensity of sunlight for initial 24 hours which indicates the fast charge transfers at high sunlight intensity. However, after 24 hours, the photocurrent was reduced to $0.01 \mathrm{~mA} / \mathrm{cm}^{2}$ due to charge recombination of electron-hole pair and also photocorrosion occur in bare $\mathrm{TiO}_{2}$ nanotubes. Nitrogen doping in the $\mathrm{TiO}_{2}$ lattice restrict the electron-hole recombination, reduce photocorrosion and thereby improve the photoactivity. ${ }^{15}, 16$ Nitrogen doping and defect-rich porous surface were effected in tuning the band-gap energy of $\mathrm{TiO}_{2}$ nanotubes by efficient overlap nitrogen and titanium orbitals. The $\mathrm{N}$-doped $\mathrm{TiO}_{2}$ nanotubes anodized for $40 \mathrm{~min}$. generated photocurrent density of $0.75 \mathrm{~mA} / \mathrm{cm}^{2}$ for 120 hours under direct sunlight illumination without any bias potential (Figure S9a). Similarly, the prepared $\mathrm{N}$-doped $\mathrm{TiO}_{2}$ nanotubes by various anodization time $(30,50,60 \mathrm{~min})$ exhibited a photocurrent density of $0.2,0.3,0.25$ $\mathrm{mA} / \mathrm{cm}^{2}$, respectively. This again confirms the role of anodization duration in photoelectrochemical activity. Moreover, the photocurrent density of 0.050 (in $1 \mathrm{M} \mathrm{H}_{2} \mathrm{SO}_{4}$ ) and $0.025 \mathrm{~mA} / \mathrm{cm}^{2}$ (in $1 \mathrm{M} \mathrm{NaOH}$ ) were corresponds to the open circuit potential of 0.5 and $0.3 \mathrm{~V}$ for $\mathrm{N}$-doped $\mathrm{TiO}_{2}$ nanotubes respectively. This result is exhibits that $\mathrm{pH}$ gradients effect is one of factor for increasing open circuit potential and photocurrent density in PEC water splitting application. 
Furthermore, the long term stability test was conducted for all samples under direct sunlight illumination in aqueous electrolytes solution. Upon comparison it is evident that $\mathrm{N}$-doped $\mathrm{TiO}_{2}$ nanotube anodized for $40 \mathrm{~min}$. shows highest stability with high efficiency in solar to hydrogen generation. The nitrogen doping and $\mathrm{pH}$ gradient had major effects on the enhancement of the PEC activity and stability of $\mathrm{TiO}_{2}$ nanotubes. Nitrogen could reduce the band gap of titania to enlarge its absorption in the visible light region and It boosts the separation efficiency of the photoinduced electron and hole. A two electrode PEC cell constructed using the photoanode demonstrates current density of $0.625 \mathrm{~mA} / \mathrm{cm}^{2}$ at 80000 lux as shown in Figure S9b and S9c . In addition, we were measured various intensity of sunlight at day time from 9 am to $4 \mathrm{pm}$ (Indian Stand Time (IST)). The photocurrent density of $0.365 \mathrm{~mA} / \mathrm{cm}^{2}$ was obtained at 9 am (50000 lux) and photocurrent density of $0.75 \mathrm{~mA} / \mathrm{cm}^{2}$ was observed at $1 \mathrm{pm}$ with maximum intensity of 100000 lux for $\mathrm{N}$-doped $\mathrm{TiO}_{2}$ nanotubes - 40 mins sample as shown $\mathrm{S} 9 \mathrm{a}$. The photoresponse parameters obtained from the present study are summarized in table S1. 


\section{REFERENCES}

1. Chen, X.; Lou, Y.; Samia, A. C. S.; Burda, C.; Gole, J. L. Formation of oxynitride as the photocatalytic enhancing site in nitrogen-doped titania nanocatalysts: comparison to a commercial nanopowder, Adv. Funct. Mater. 2015, 15, 41-49.

2. Tong, X.; Yang, P.; Wang, Y.; Qin Y.; Guo, X. Enhanced photoelectrochemical watersplitting performance of $\mathrm{TiO}_{2}$ nanotube arrays coated with an ultrathin nitrogen-doped carbon film by molecular layer deposition, Nanoscale 6, 6692-6700 (2014).

3. Umar, A. A.; Rahman, M. Y. A.; Saad, S. K. M.; Salleh, M. M. Effect of $\mathrm{NH}_{3}$ concentration on the performance of nitrogen doped $\mathrm{TiO}_{2}$ photoelectrochemical Cell, Int. J. Electrochem. Sci. 2012, 7, $7855-7865$.

4. Wang, J.; Zhu, W.; Zhang, Y.; Liu, S. An efficient two-step technique for nitrogen-doped titanium dioxide synthesizing: visible-light-induced photodecomposition of methylene blue $J$. Phys. Chem. C 2007, 111, 1010-1014.

5. Jagadale, T. C.; Takale, S. P.; Sonawane, R. S.; Joshi, H. M.; Patil, S. I.; Kale, B. B.; Ogale, S. B. N-doped $\mathrm{TiO}_{2}$ nanoparticle based visible light photocatalyst by modified peroxide sol-gel method, J. Phys. Chem. C 2008, 112, 14595-14602.

6. Kolile, U.; Moser, J.; Gratzel, M. Dynamics of interfacial charge-transfer reactions in semiconductor dispersions reduction of cobaltoceniumdicarboxylate in colloidal $\mathrm{TiO}_{2}$ Inorg. Chem. 1985, 24, 2253-2258 ().

7. Dong, J.; Han, J.; Liu, Y.; Nakajima, A.; Matsushita, S.; Wei, S.; Gao, W. Defective black $\mathrm{TiO}_{2}$ synthesized via anodization for visible-light photocatalysis, Appl. Mater. Interfaces 2014, 6, 1385-1388. 
8. Zeng, L.; Lu, Z.; Li, M.; Yang, J.; Song W.; Zeng, D.; Xie, C. A modular calcination method to prepare modified $\mathrm{N}$-doped $\mathrm{TiO}_{2}$ nanoparticle with high photocatalytic activity, Applied Catalysis B: Environmental 2016, 183, 308-316.

9. Hernandez-Pagan, E. A.; Vargas-Barbosa, N. M.; Wang, T.; Zhao, Y.; Smotkinb, E. S.; Mallouk, T. E. Resistance and polarization losses in aqueous buffer-membrane electrolytes for water-splitting photoelectrochemical cells, Energy Environ. Sci. 2012, 5, 7582-7589.

10. Sun, K.; Liu, R.; Chen, Y.; Verlage, E.; Lewis , N. S.; Xiang. C. A stabilized, intrinsically safe, $10 \%$ effi cient, solar driven water-splitting cell incorporating earth-abundant electrocatalysts with steady-state $\mathrm{pH}$ gradients and product separation enabled by a bipolar membrane, Adv. Energy Mater. 2016, 6, 1600379-1600385.

11. Vargas-Barbosa, N. M.; Geise, G. M.; Hickner, M. A.; Mallouk, T. E. Assessing the utility of bipolar membranes for use in photoelectrochemical water-splitting cells, ChemSusChem 2014, 7, 3017-3020.

12. Selli, E.; Chiarello, G. L.; Quartarone, E.; Mustarelli, P.; Rossettia, I.; Fornia, L. A photocatalytic water splitting device for separate hydrogen and oxygen evolution, Chem. Commun. 2007, 0, 5022-5024.

13. Minggu, L. J.; Daud, W. R. W.; Kassim M. B. An overview of photocells and photoreactors for photoelectrochemical water splitting, Int. J. Hydrogen Energy 2010, 35, 5233-5244.

14. Kaplan, A.; Korin, E.; Halevy, S.; Bettelheim, A. Chemical bias of electrochemical and photoelectrochemical water splitting using a hydrogel separator, Electrochem. Commun. 2015, 60, 97-99.

15. Asahi, R.; Morikawa, T.; Ohwaki, T.; Aoki, K.; Taga, Y. Visible-light photocatalysis in nitrogen-doped titanium oxides, Science 2001, 293, 269-271. 
16. Gratzel, M. The artificial leaf, bio-mimetic photocatalysis, Cattech 1999, 3, 4-17.

17. Babu, V. J.; Kumar, M. K.; Nair, A. S.; Kheng, T. L.; Allakhverdiev S. I.; Ramakrishna, S. Visible light photocatalytic water-splitting for hydrogen production from $\mathrm{N}^{-\mathrm{TiO}_{2}}$ rice grain shaped electrospun nanostructures, Int. J. Hydrogen Energy 2002, 37, 8897-8904.

18. Khan, S. U. M.; Shahry, M. A.; Ingler, W. B. Efficient photochemical water-splitting by a chemically modified n- $\mathrm{TiO}_{2}$, Science 2002, 297, 2243-2245.

19. Umar, A. A.; Rahman, M. Y. A.; Saad, S. K. M.; Salleh, M. M. Effect of $\mathrm{NH}_{3}$ concentration on the performance of nitrogen doped $\mathrm{TiO}_{2}$ photoelectrochemical Cell, Int. J. Electrochem. Sci. 2012, 7, $7855-7865$.

20. Lindgren, T.; Hoel, A.; Granqvist, C. G.; Torres G. R.; Lindquist, S. E. Photoelectrochemical study of sputtered nitrogen-doped titanium dioxide thin films in aqueous electrolyte, Sol. Ener. Mater. Sol. Cells 2004, 84, 145-157.

21. Sokol, K. P.; Robinson, W. E.; Warnan, J.; Kornienko, N.; Nowaczyk, M. M.; Ruff, A.; Zhang, J. Z. Reisner, E. Bias-free photoelectrochemical water splitting with photosystem II on a dye-sensitized photoanode wired to hydrogenase, Nat.Energy, 2018, 3, 944-951. 


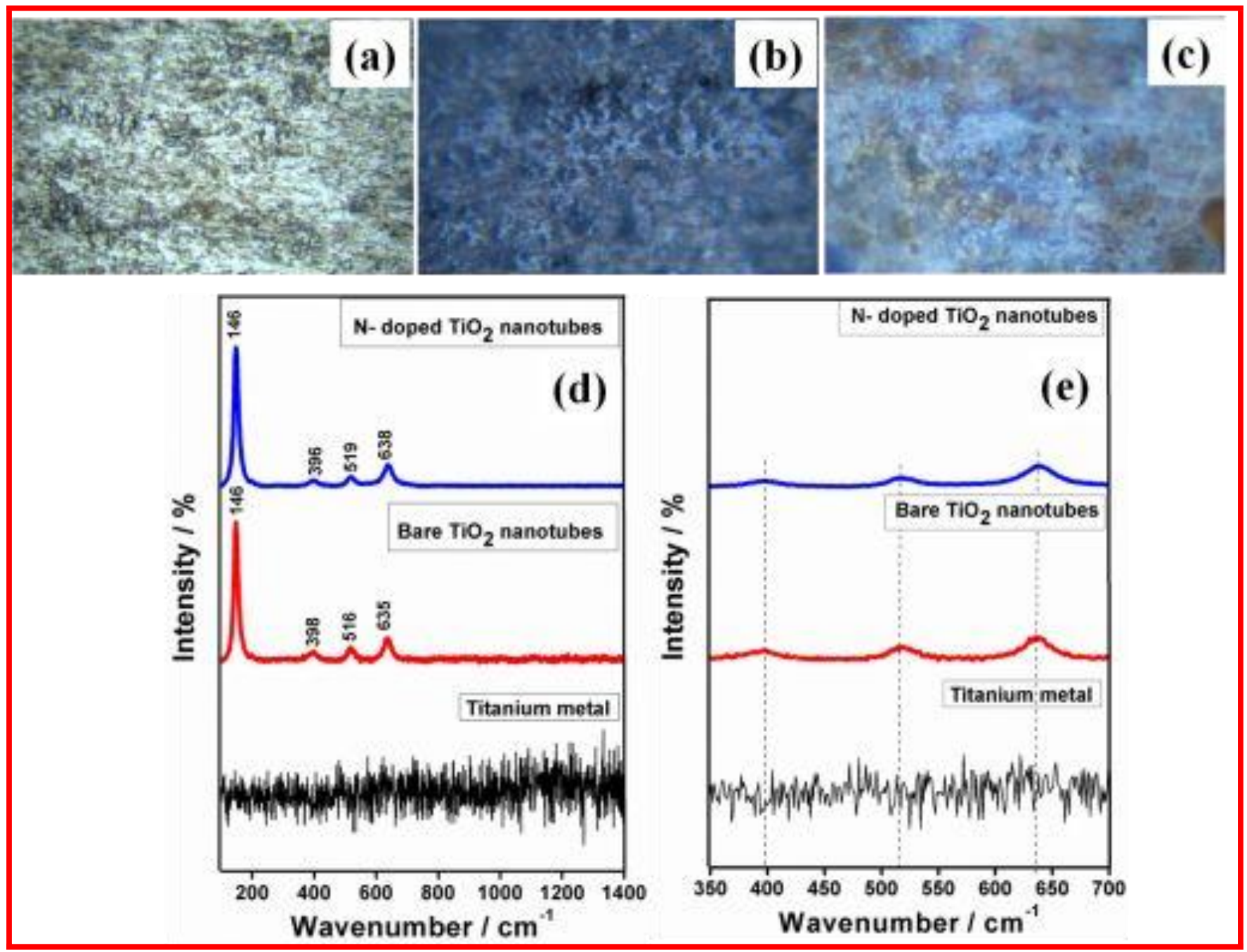

Figure S1. $(\mathrm{a}-\mathrm{c})$ the surface microscopy images and (d) Raman spectra of titanium foil, bare and N-doped $\mathrm{TiO}_{2}$ nanotubes respectively. (e) The expansion Raman spectra of titanium foil, bare and $\mathrm{N}$-doped $\mathrm{TiO}_{2}$ nanotubes respectively. 


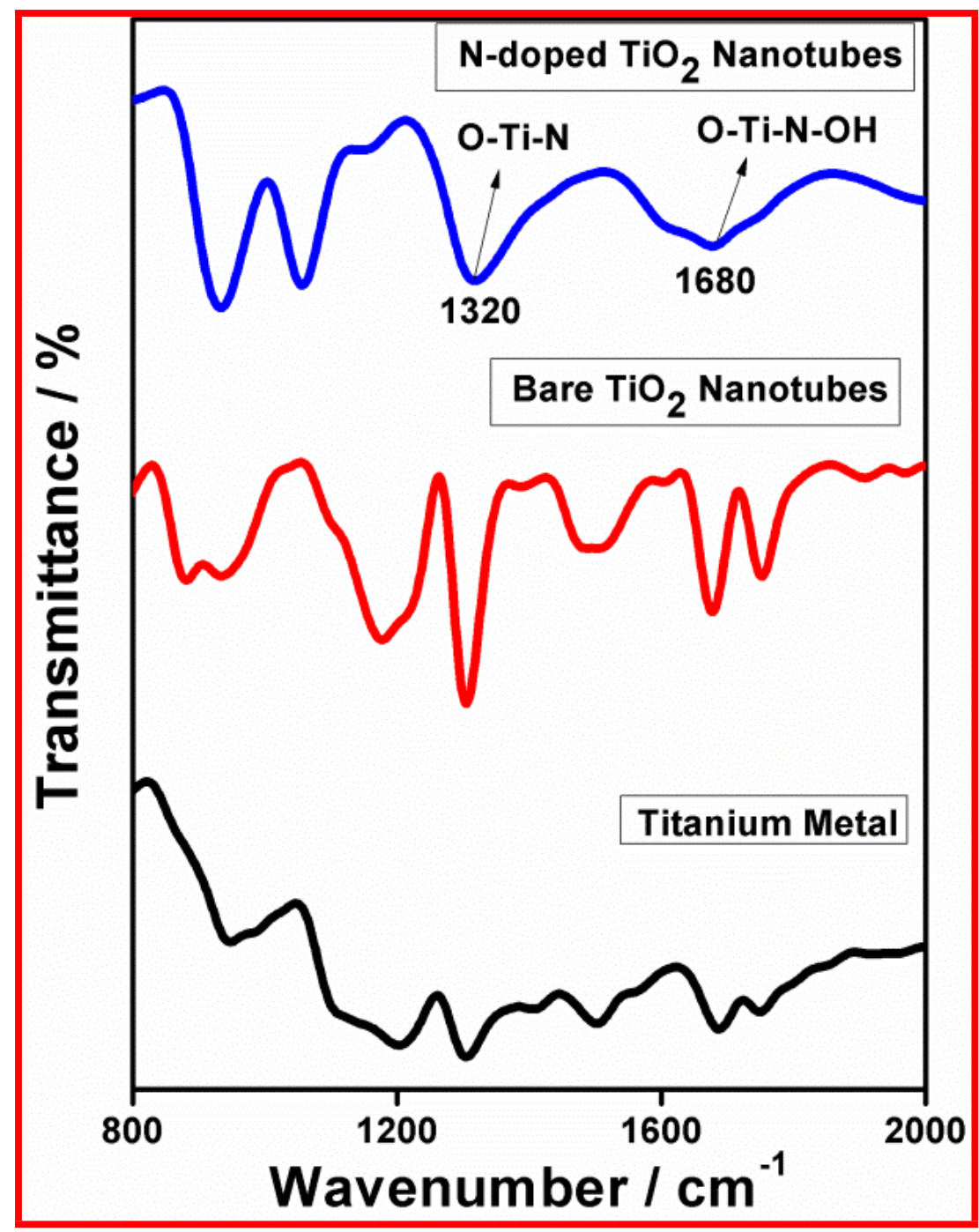

Figure S2. FT-IR spectra of titanium metal, bare and N-doped $\mathrm{TiO}_{2}$ nanotubes. 


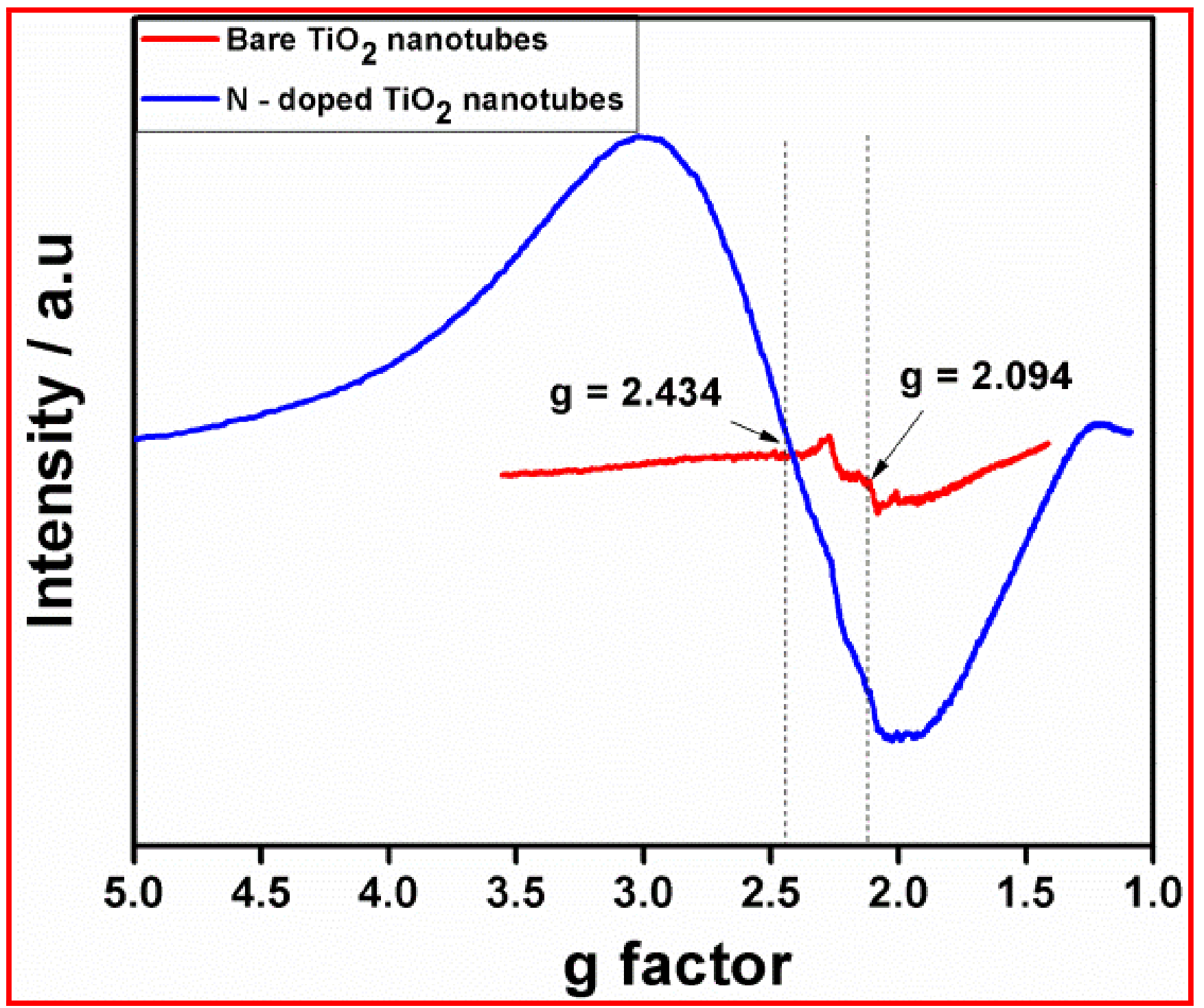

Figure S3. The EPR spectra of bare and $\mathrm{N}$-doped $\mathrm{TiO}_{2}$ nanotubes. 

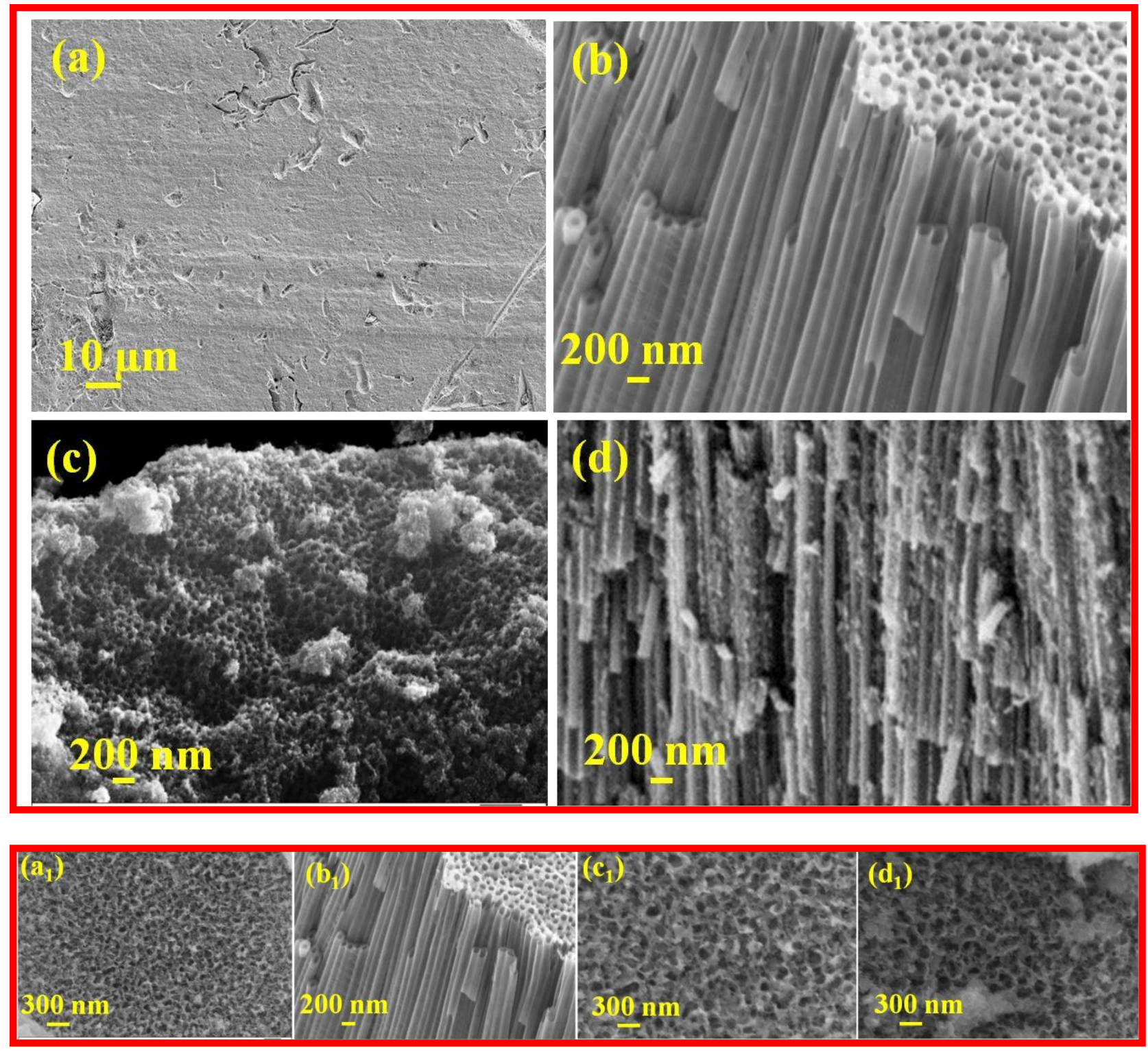

Figure S4. FE-SEM images of (a) titanium metal, (b) cross sectional of bare $\mathrm{TiO}_{2}$ nanotubes and $(c-d)$ surface morphology and cross sectional of $\mathrm{N}$-doped $\mathrm{TiO}_{2}$ nanotubes. $\left(\mathrm{a}_{1}-\mathrm{d}_{1}\right)$ images of surface morphology of different anodization time of $\mathrm{N}$-doped $\mathrm{TiO}_{2}$ nanotubes $(30,40,50$ and 60 min.). 


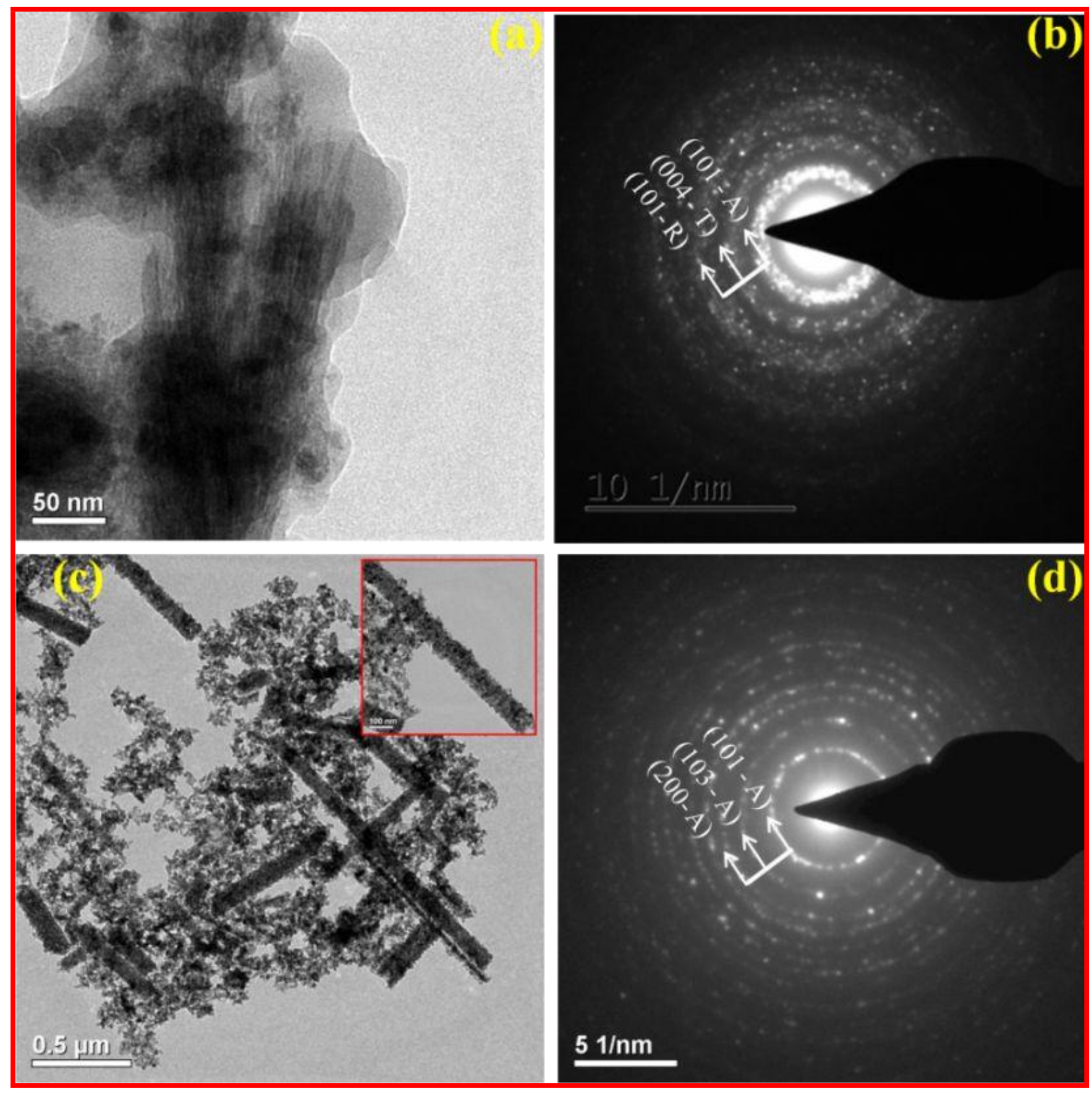

Figure S5. (a) \& (c) the TEM images of bare and $\mathrm{N}$-doped $\mathrm{TiO}_{2}$ nanotubes. (b) \& (d) corresponding SAED patterns. 


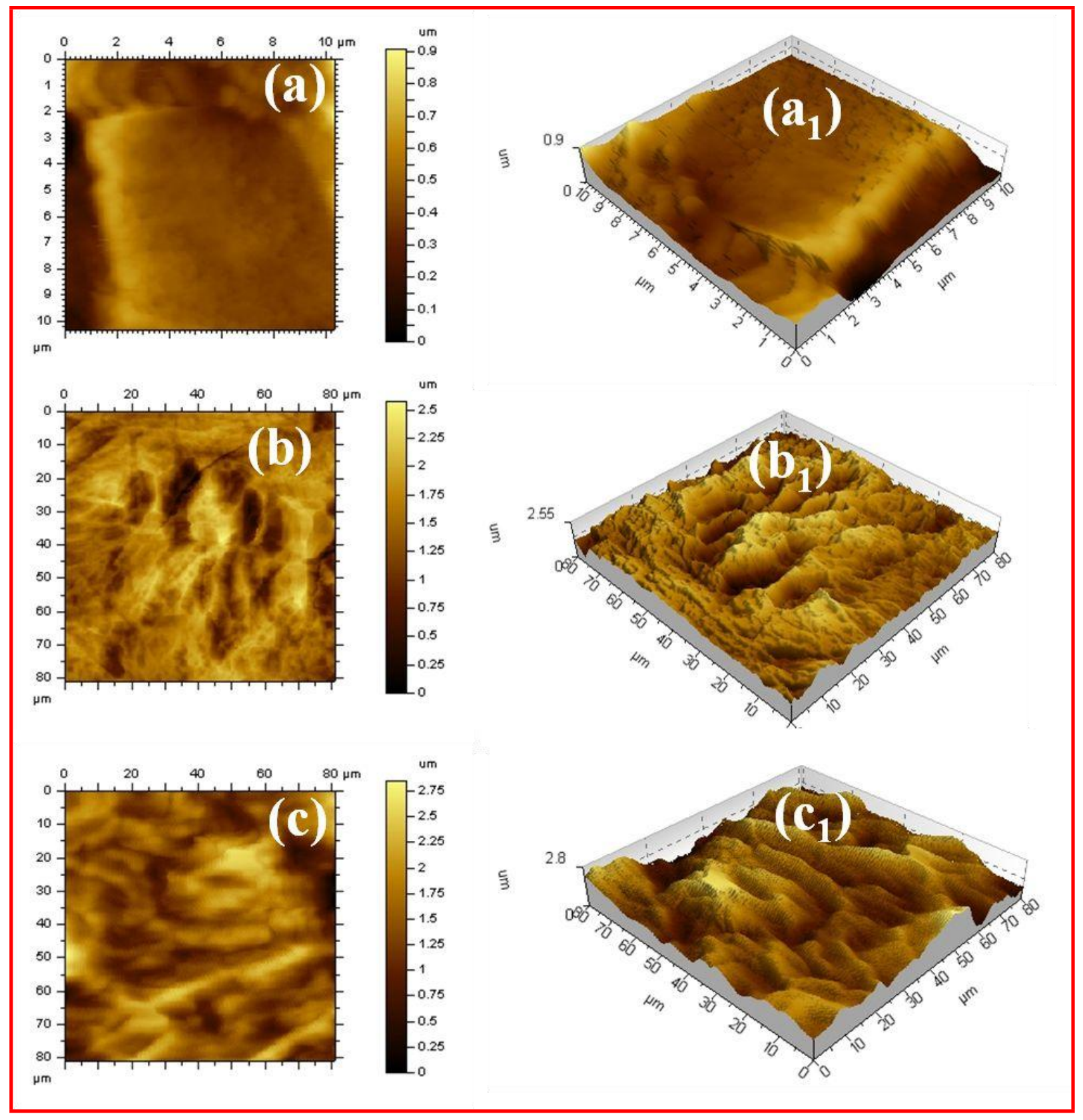

Figure S6. (a-c) atomic force microscope topographic; $\left(\mathrm{a}_{1}-\mathrm{c}_{1}\right) 3 \mathrm{D}$ images of titanium, bare- $\mathrm{TiO}_{2}$ nanotubes and $\mathrm{N}$-doped nanotubes. 


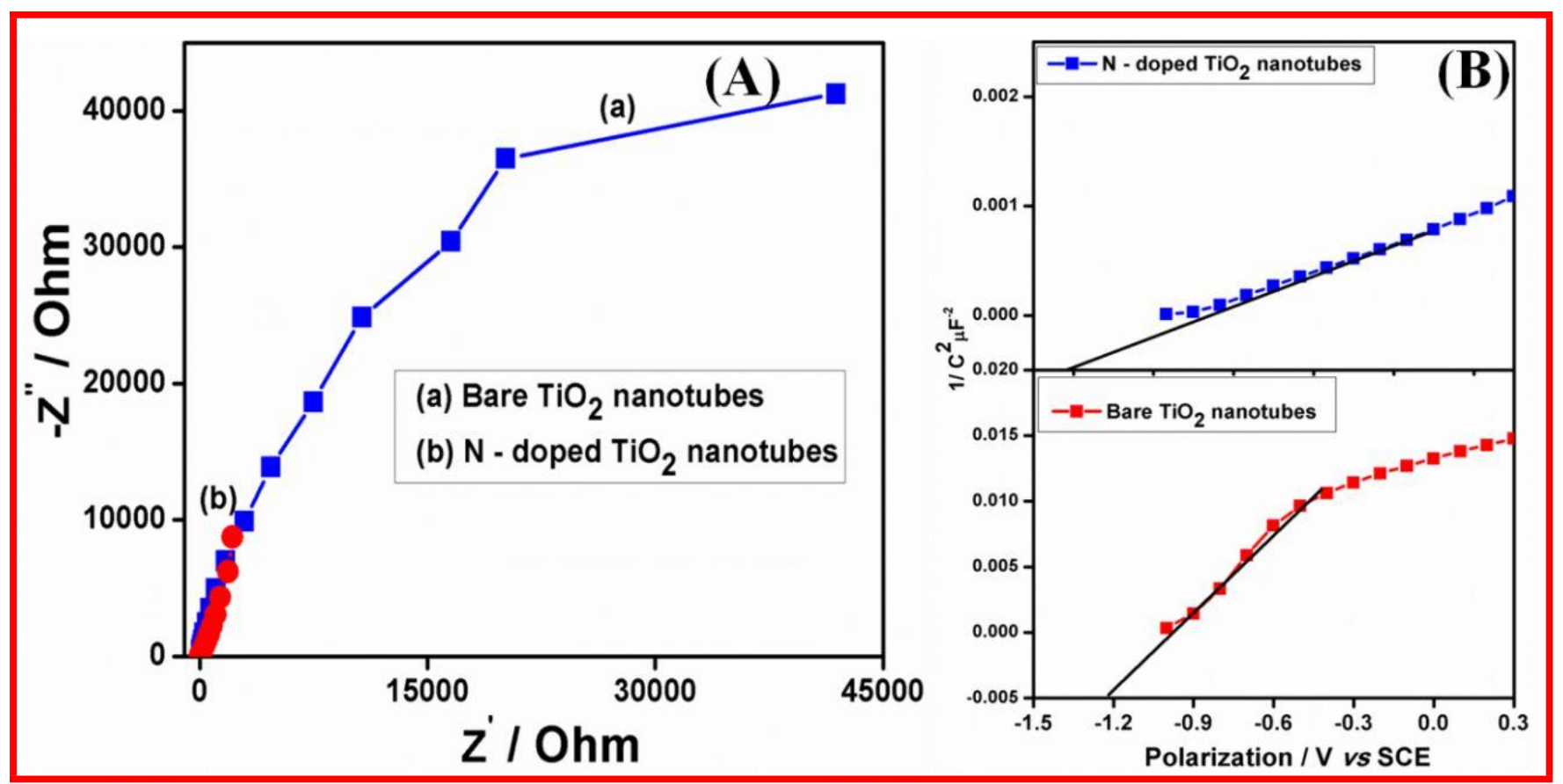

Figure S7. A \& B shows EIS Nyquist and Mott-Schottky plots of bare and N-doped $\mathrm{TiO}_{2}$ nanotubes under the xenon light illumination in aqueous electrolytes of $1 \mathrm{M} \mathrm{NaOH}(14 \mathrm{pH}) / 1 \mathrm{M}$ $\mathrm{H}_{2} \mathrm{SO}_{4}(1 \mathrm{pH})$ solution.

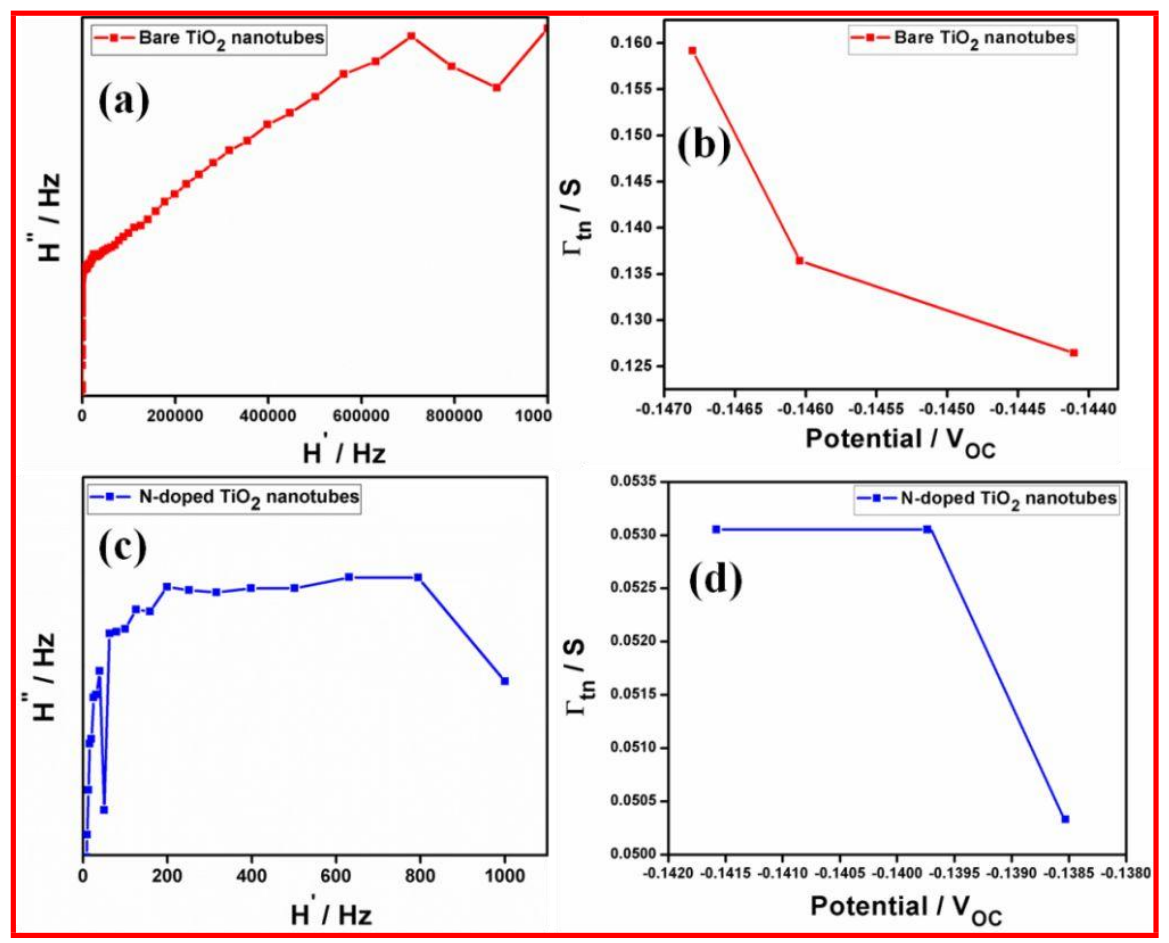

Figure S8. IMVS studies for bare and $\mathrm{N}$-doped $\mathrm{TiO}_{2}$ nanotubes at open circuit potential. 


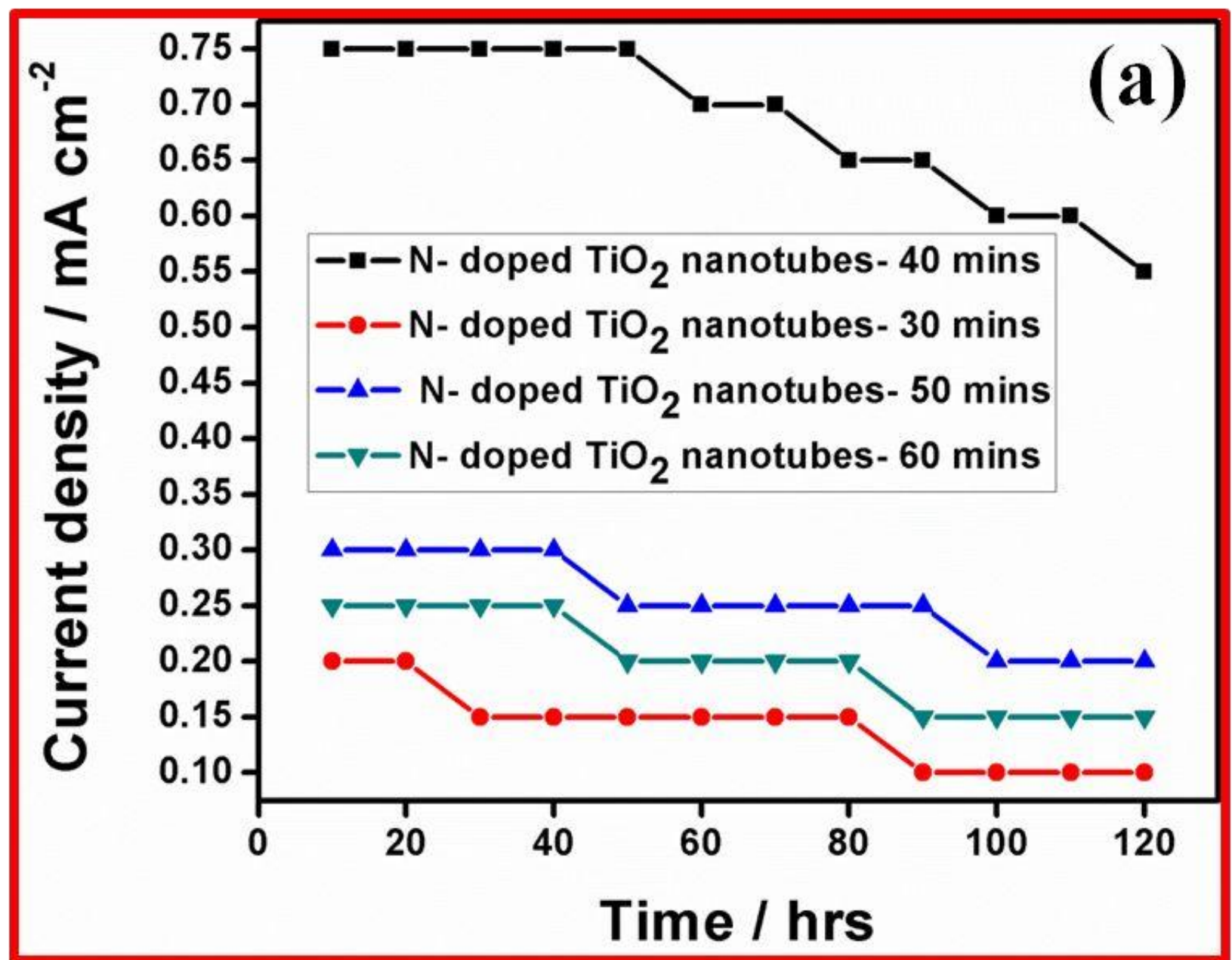

Figure S9. a) outdoor PEC water-splitting measurement of $\mathrm{N}$-doped $\mathrm{TiO}_{2}$ nanotubes at directs sunlight illumination in aqueous electrolytes of $1 \mathrm{M} \mathrm{NaOH}(14 \mathrm{pH}) / 1 \mathrm{M} \mathrm{H}_{2} \mathrm{SO}_{4}(1 \mathrm{pH})$ solution. 


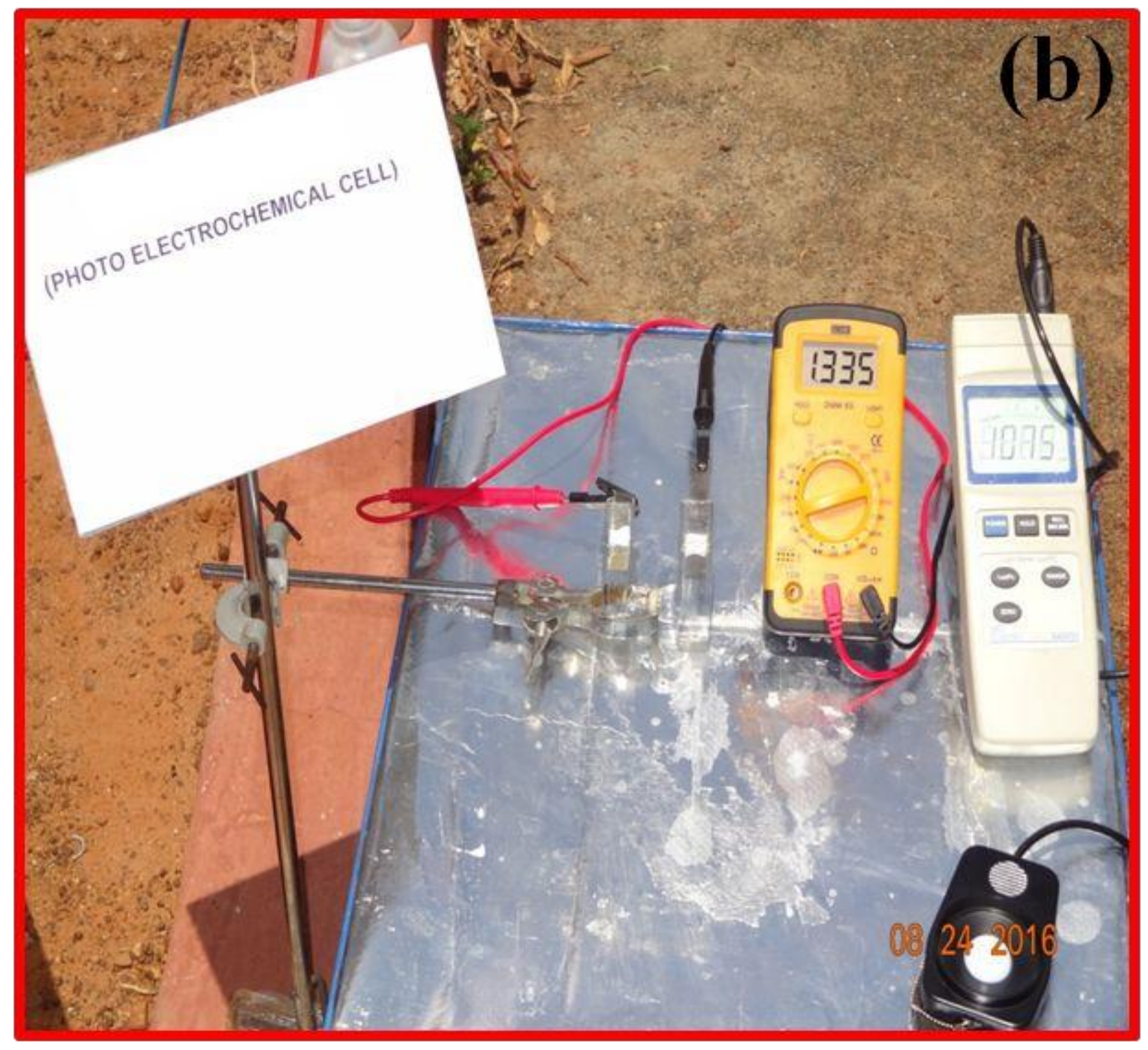

Figure S9. b) The voltage measurement of $\mathrm{N}$-doped $\mathrm{TiO}_{2}$ nanotubes for outdoor PEC watersplitting experimental (direct sunlight illumination). 


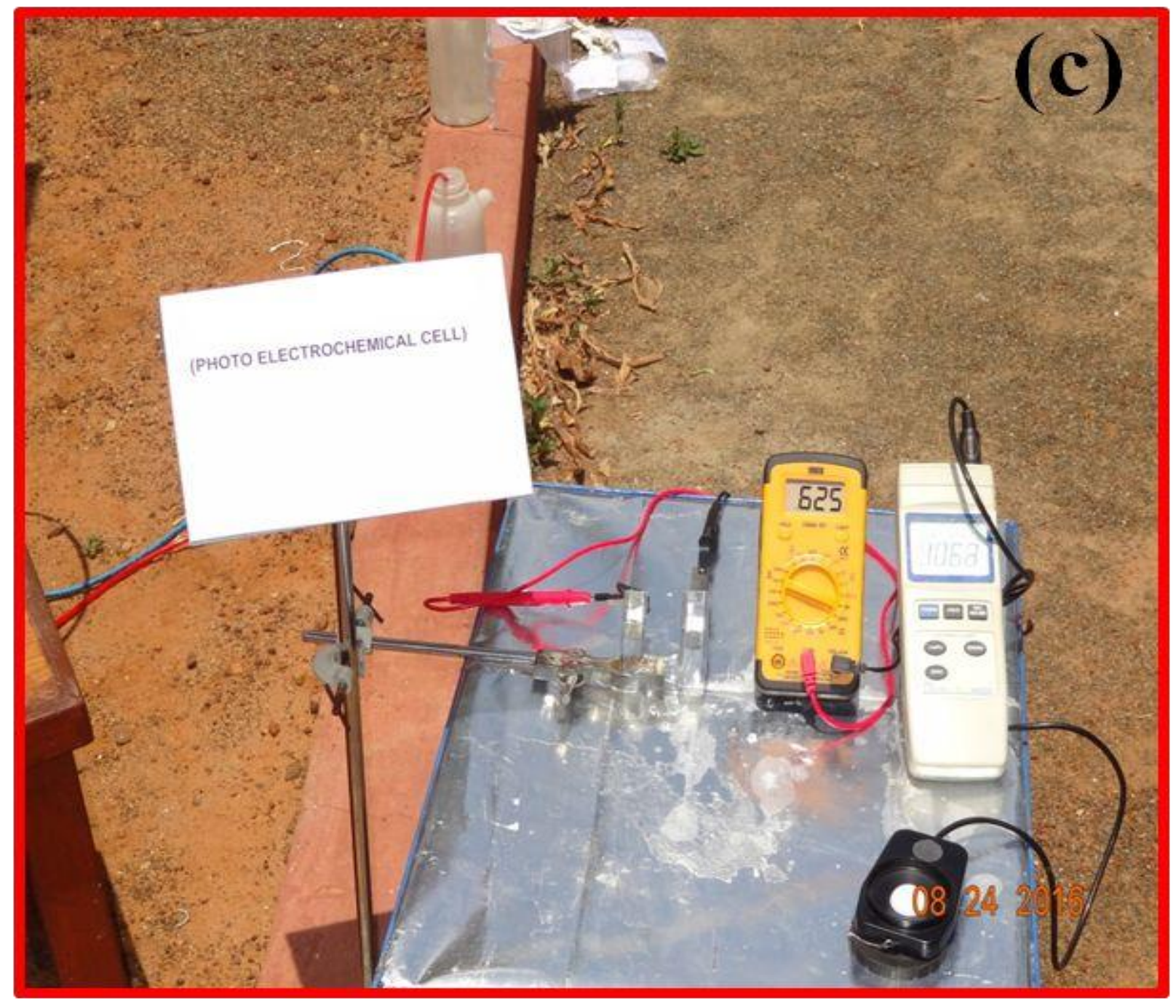

Figure S9. c) The photocurrent density measurement of $\mathrm{N}$-doped $\mathrm{TiO}_{2}$ nanotubes for outdoor PEC water-splitting experimental (direct sunlight illumination). 

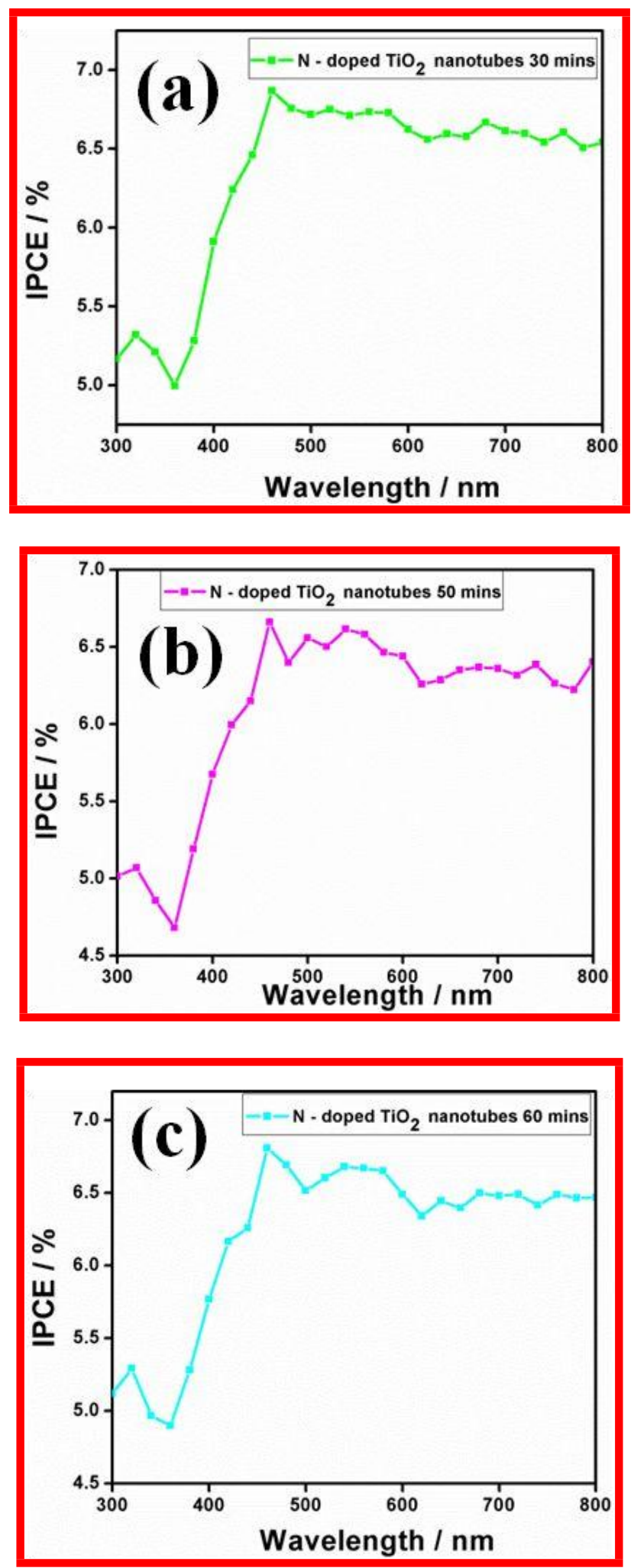

Figure $\mathrm{S} 10 . \mathrm{a}), \mathrm{b}$ ) and c) IPCE studies of $\mathrm{N}$-doped $\mathrm{TiO}_{2}$ nanotubes (with different anodization time at 30,50 and 60 mins) in $1 \mathrm{M} \mathrm{NaOH}$ solution. 


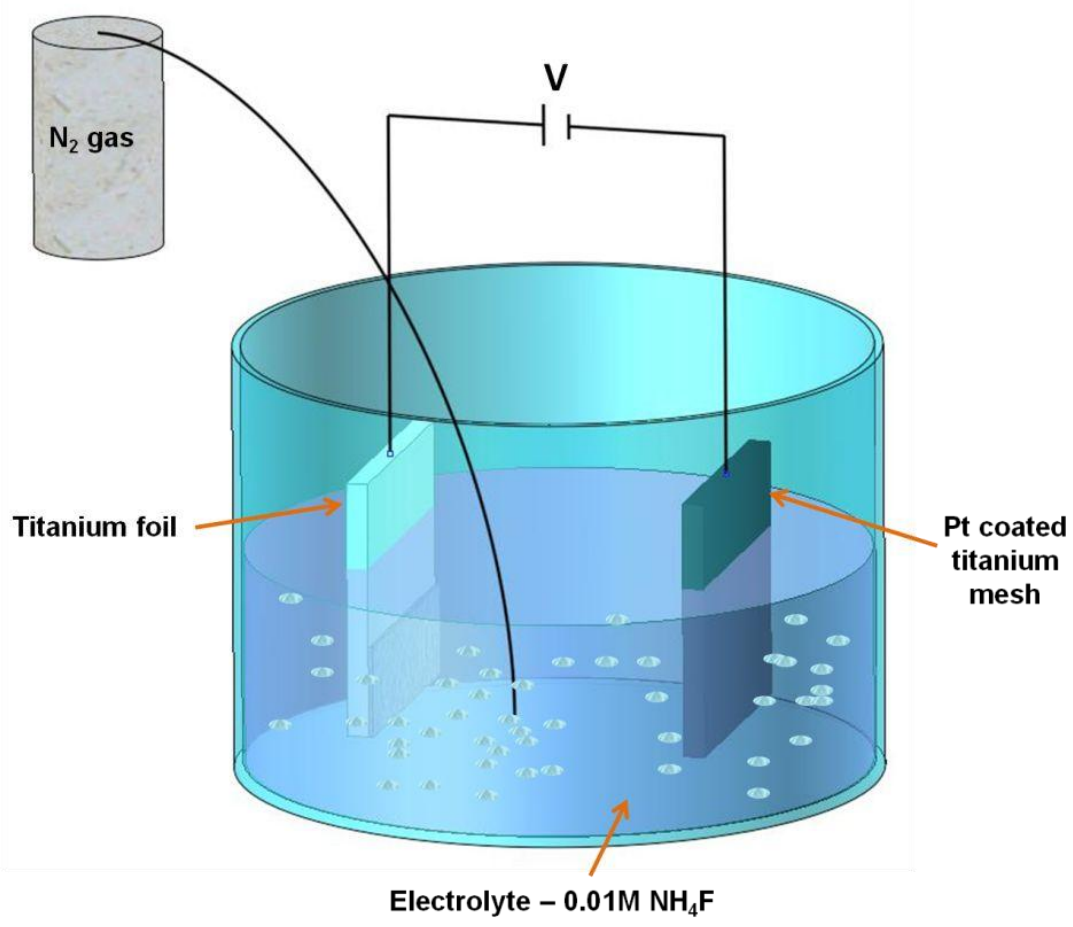

Scheme S1. Illustrates the preparation of in-situ $\mathrm{N}$-doped $\mathrm{TiO}_{2}$ nanotubes via electrochemical anodization process in nitrogen atmosphere.

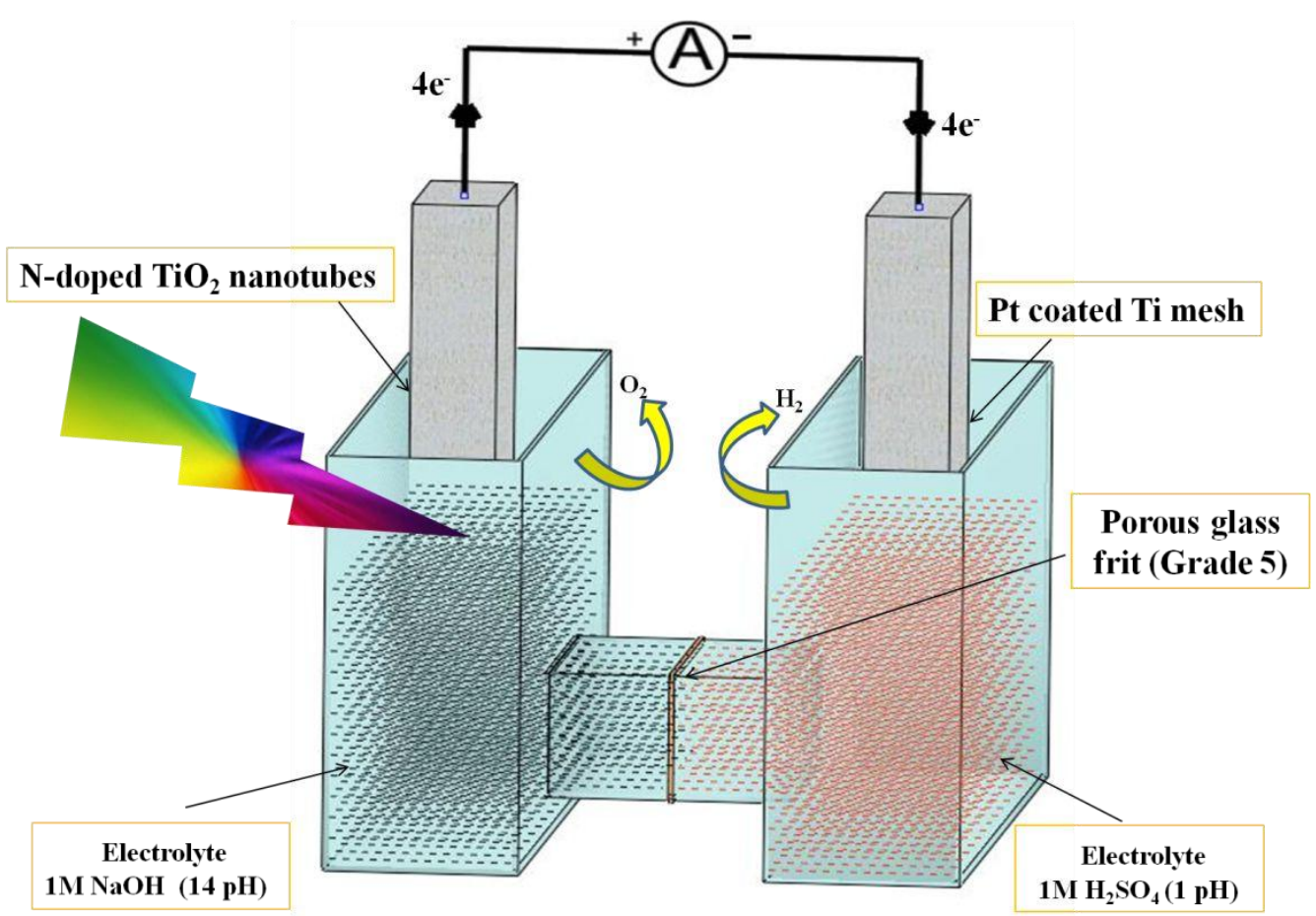

Scheme S2. Schematic of Photoelectrochemical with $\mathrm{pH}$ gradients. 
Table S1. The current density and solar efficiency of $\mathrm{N}$-doped $\mathrm{TiO}_{2}$ nanotubes for various time anodization titanium metal subrates.

The solar to hydrogen (STH) was calculated by,

$$
\eta=(1.23 \mathrm{~V})\left(\mathrm{J}_{\mathrm{OP}}\right) / \mathrm{P}_{\text {in }}
$$

Where,

$\mathrm{J}_{\mathrm{op}}$ is the operational photocurrent density in $\mathrm{mA} \mathrm{cm}^{-2}$

$\mathrm{P}_{\mathrm{in}}$ is the incident irradiance in $\mathrm{mW} \mathrm{cm}-2$

\begin{tabular}{cccc}
\hline S.No & Catalysts & Current density $/ \mathrm{mA} \mathrm{cm}^{-2}$ & $\mathrm{STH} / \%$ \\
\hline 1. & $\mathrm{N}-\mathrm{TiO}_{2}-30$ mins & 0.2 & 0.15 \\
2. & $\mathrm{N}-\mathrm{TiO}_{2}-40$ mins & 0.75 & 0.5 \\
3. & $\mathrm{N}-\mathrm{TiO}_{2}-50$ mins & 0.3 & 0.25 \\
4. & $\mathrm{N}-\mathrm{TiO}_{2}-60$ mins & 0.25 & 0.2 \\
\hline
\end{tabular}


Table S2. The comparison of PEC studies for various materials.

\begin{tabular}{|c|c|c|c|c|c|}
\hline $\begin{array}{l}\text { Publication } \\
\text { institute(s) }\end{array}$ & \multicolumn{2}{|c|}{ Device structure } & $\begin{array}{l}\text { olyte and illumination } \mathrm{S} \\
\text { conditions }\end{array}$ & $\begin{array}{l}\text { STH efficiency } \\
\text { (\%) }\end{array}$ & Stability \\
\hline $\begin{array}{l}\text { Walczak et al. } \\
\text { (Chem SusChem-2015) } \\
\text { LBNL, Caltech, JCAP }\end{array}$ & \multicolumn{2}{|c|}{$\begin{array}{c}\mathrm{c}-\mathrm{Si}\left(\mathrm{pn}^{+}\right) / / \mathrm{c}-\mathrm{Si}\left(\mathrm{p}^{+} \mathrm{n}\right) / / \mathrm{WO}_{3} \mathrm{SLJ} \\
\text { monolithic } \mathrm{PV} \text { Integrated } \\
\mathrm{Pt} \mathrm{HER} \text { catalyst } \\
\text { with } \mathrm{TiO}_{2} \text { passivation layer }\end{array}$} & $\begin{array}{c}1 \mathrm{M} \mathrm{HClO}_{4} \\
\text { electrolyte } \\
\text { Membrane Nafion } \\
\mathrm{XL} 200 \mathrm{~mW} \mathrm{~cm}^{-2}\end{array}$ & 0.24 & $\begin{array}{c}20 \text { hours } \\
\text { stable } \\
\mathrm{H}_{2} \text { generation } \\
\text { tested to } 48 \\
\text { hours }\end{array}$ \\
\hline $\begin{array}{c}\text { Bornoz et al. } \\
\text { (2014-J. Phys. Chem. C) } \\
\text { EPFL, Institute for Solar } \\
\text { Fuels, } \\
\text { Delft University }\end{array}$ & \multicolumn{2}{|c|}{$\begin{array}{c}\mathrm{SLJ} \mathrm{Cu} \mathrm{O}_{2} \mathrm{O}(\mathrm{p}) / / \mathrm{BiVO}_{4}(\mathrm{n}) \mathrm{SLJ} \\
\text { wired PV integrated RuOX HER } \\
\text { catalyst } \\
\text { integrated CoPi OER catalyst }\end{array}$} & $\begin{array}{c}\mathrm{K}_{3^{-} \times} \mathrm{H}_{\mathrm{x}} \mathrm{PO}_{4} \text { buffer, } \\
\mathrm{pH} 6 \text { co-evolved } \\
\text { products } \\
100 \mathrm{~mW} \mathrm{~cm}^{-2}\end{array}$ & 0.5 & $\begin{array}{l}2 \text { min } \\
20 \% \text { current } \\
\text { loss }\end{array}$ \\
\hline $\begin{array}{l}\text { Shaner et al. (Energy } \\
\text { and Environmental } \\
\text { Science-2014) } \\
\text { Caltech, JCA }\end{array}$ & \multicolumn{2}{|c|}{$\begin{array}{l}\mathrm{c}-\mathrm{Si}(\mathrm{pn}) / / \mathrm{WO}_{3}(\mathrm{n}) \mathrm{SLJ} \text { core-shell } \\
\text { nanowire monolithic } \mathrm{PV} \text { wired } \mathrm{Pt} \\
\text { cathode }\end{array}$} & $\begin{array}{c}1 \mathrm{M} \mathrm{H}_{2} \mathrm{SO}_{4} \text { co-evolved } \\
\text { products } 1080 \mathrm{~mW} \mathrm{~cm}{ }^{-2} \\
\text { (11 suns) }\end{array}$ & 0.0068 & $\begin{array}{l}10 \text { min } \\
\text { stable current }\end{array}$ \\
\hline \multicolumn{2}{|c|}{$\begin{array}{c}\text { Fujishima et al. (Nature-1972) } \\
\text { Department of applied } \\
\text { chemistry, } \\
\text { Kanagawa university, yokohama. }\end{array}$} & $\begin{array}{l}\text { PEC configuration } \\
\text { Photoanode- } \mathrm{TiO}_{2} \\
\text { Cathode-Pt black }\end{array}$ & $\begin{array}{l}\text { Electrolyte } \\
\text { Aqueous electrolyte }(\mathrm{pH}-4.7) \\
\text { Illumination under sunlight }\end{array}$ & 0.1 & - \\
\hline \multicolumn{2}{|c|}{$\begin{array}{l}\text { Ohashi. K et al. (Nature - 1977) } \\
\text { Osaka city university, } \\
\text { faculty of engineering, osaka, } \\
\text { Japan }\end{array}$} & $\mathrm{n}-\mathrm{TiO}_{2} / \mathrm{p}-\mathrm{GaP}$ & $\begin{array}{l}\text { Electrolyte } \\
1 \mathrm{M} \mathrm{NaOH}\end{array}$ & 0.1 & - \\
\hline $\begin{array}{c}\text { CSIR - CECRI } \\
\text { Karaikudi, Tamilnadu } \\
\text { India }\end{array}$ & & $\begin{array}{l}\text { PEC configuration } \\
\text { Photoanode- } \mathrm{TiO}_{2}-\mathrm{N} \\
\text { Cathode-Pt black }\end{array}$ & $\begin{array}{c}\text { Electrolyte } \\
1 \mathrm{M} \mathrm{NaOH} / 1 \mathrm{M} \mathrm{H}_{2} \mathrm{SO}_{4} \\
\text { Illumination under sunlight }\end{array}$ & 0.5 & 120 hours \\
\hline
\end{tabular}


Table S3. Solar-to-Hydrogen efficiency of $\mathrm{N}$-doped $\mathrm{TiO}_{2}$ synthesized by various methods.

\begin{tabular}{|c|c|c|c|c|c|c|}
\hline S.No & $\begin{array}{l}\text { Photoelectrochemical } \\
\text { catalysts }\end{array}$ & $\begin{array}{l}\text { Synthesis } \\
\text { methods }\end{array}$ & $\begin{array}{l}\text { Solar-to-Hydrogen } \\
\text { efficiency (\%) }\end{array}$ & $\begin{array}{l}\text { Stability } \\
\text { (hours) }\end{array}$ & Electrolytes & References \\
\hline 1. 1 & $\begin{array}{l}\mathrm{N}-\mathrm{TiO}_{2} \text { nano raise grain } \\
\text { shape }\end{array}$ & $\begin{array}{l}\text { Sol-gel and electro- } \\
\text { spinning }\end{array}$ & 0.8 & - & $0.5 \mathrm{M} \mathrm{Na}_{2} \mathrm{SO}_{4}$ & (17) \\
\hline & $\begin{array}{l}\mathrm{CM}-\mathrm{n}-\mathrm{TiO}_{2} \text { nano porous } \\
\text { surface }\end{array}$ & Thermal treatment & 8.35 & - & $5 \mathrm{M} \mathrm{KOH}$ & (18) \\
\hline 3. & $\begin{array}{c}\mathrm{n}-\mathrm{TiO}_{2} \text { nano porous } \\
\text { surface }\end{array}$ & Thermal treatment & 1.08 & - & $5 \mathrm{M} \mathrm{KOH}$ & (18) \\
\hline 3. & $\begin{array}{l}\text { Anatase phase } \mathrm{N} \text {-doped } \\
\qquad \mathrm{TiO}_{2}\end{array}$ & Liquid phase deposition & 0.14 & - & $\begin{array}{c}0.5 \mathrm{M} \\
\text { tetrabutylammonium } \\
\text { and } 0.5 \mathrm{M} 4- \\
\text { tertbutylpyridine in } \\
\text { acetonitrile }\end{array}$ & (19) \\
\hline 4. & $\mathrm{~N}$-doped $\mathrm{TiO}_{2}$ & Thin film sputtering & 11 (Theoretical value) & - & $0.5 \mathrm{M} \mathrm{NaOH}$ & (20) \\
\hline 5. & Dye sensitized $-\mathrm{TiO}_{2}$ & Thin film deposition & 0.14 & $120(\mathrm{~min})$ & $\begin{array}{c}20 \mathrm{mM} \mathrm{CaCl}_{2} / \\
15 \mathrm{mM} \mathrm{MgCl}_{2} / \\
50 \mathrm{mM} \mathrm{KCl}\end{array}$ & (21) \\
\hline 6. & $\mathrm{~N}$-doped $\mathrm{TiO}_{2}$ Nanotubes & $\begin{array}{l}\text { Electrochemical } \\
\text { anodization }\end{array}$ & 0.5 & 120 & $1 \mathrm{M} \mathrm{NaOH} / 1 \mathrm{M} \mathrm{H}_{2} \mathrm{SO}_{4}$ & $\begin{array}{l}\text { Present } \\
\text { work }\end{array}$ \\
\hline
\end{tabular}

